\title{
EKSTRAKSI KEMIRI DENGAN METODE SOXHLET DAN KARAKTERISASI MINYAK KEMIRI
}

\author{
Ariestya Arlene \\ Jurusan Teknik Kimia, Fakultas Teknologi Industri, Universitas Katolik Parahyangan \\ Jl. Ciumbuleuit 94, Bandung 40141, Indonesia, Telp: (022)2032700, Fax: (022)2032700 \\ e-mail: ariestya.arlene@unpar.ac.id
}

\begin{abstract}
Abstrak
Kemiri berasal dari Kepulauan Hawaii. Tanaman ini kemudian menyebar ke negara lain, termasuk Indonesia, dan pertama kali tumbuh di Maluku. Kemiri menjadi komoditas dalam negeri dan juga komoditas ekspor di Indonesia. Kemiri dikenal masyarakat karena bijinya sering digunakan sebagai bumbu masak. Biji kemiri memiliki kandungan minyak yang tinggi, yaitu 50-60\% dari berat biji. Fungsi minyak kemiri adalah sebagai penyubur rambut, bahan pelapis cat, dan bahan pernis. Dengan penelitian yang lebih mendalam, diharapkan minyak kemiri dapat diaplikasikan lebih luas.Tujuan penelitian ini adalah mengambil minyak kemiri dari bijinya secara maksimal dengan metode ekstraksi Soxhlet dengan kualitas yang baik. Manfaat penelitian ini adalah memberikan masukan dan informasi pelarut yang terbaik pada ekstraksi biji kemiri sehingga dapat meningkatkan pendayagunaan sumber daya alam biji kemiri dan dapat mendukung industri lainnya. Metodologi penelitian yang digunakan pada penelitian ini terdiri dari perlakuan awal biji kemiri, ekstraksi Soxhlet biji kemiri dengan pelarut aseton, etanol, dan n-heksana. Kemudian dilanjutkan dengan analisis minyak kemiri yang diperoleh. Kesimpulan yang dapat diambil dari penelitian ini adalah pelarut yang menghasilkan rendemen paling tinggi dalam mengekstrak minyak dari biji kemiri adalah nheksana, dengan nilai rendemen 74,57\% dari berat biji. Namun, kualitas terbaik minyak kemiri terjadi pada ekstraksi pelarut etanol, dengan nilai bilangan asam 8,27 gram KOH/gram minyak.
\end{abstract}

Kata kunci: soxhlet, kemiri, aseton, etanol, n-heksana.

\begin{abstract}
Candlenut is originally from Hawaii. This plant is then spread all over the countries, including Indonesia, and firstly grow in Maluku. Candlenut becomes domestic and foreign commodities in Indonesia. This plant is known well because the seed is often used as the cooking ingredient. The seed of candlenut contains a large amount of oil, which is 50-60\% from the mass of the seed. Candlenut oil is used as hair fertilizer, paint materials, and varnish material. With further research, candlenut oil is expected to be applied in wider scope. The aim of this research is to extract the candlenut oil from its seed maximally with Soxhlet extraction method. The benefit of this research is to give inputs and information about the suitable solvent that influence the oil extraction from candlenut seed, which can increase the use of candlenut as natural resource and support the other industries. The method of this research consists of early treatment of candlenut seed, Soxhlet extraction with acetone, ethanol, and n-hexane as solvent, then continued with the analysis of the oil. The conclusion of this research are the solvent which produce the highest yield in oil extraction of candlenut seed is $n$-hexane, with the yield value is $74,57 \%$ from the mass of the seed. However, the best quality of the candlenut oil is obtained from extraction with ethanol as the solvent, with the acid value is 8,27 gram KOH/gram oil.
\end{abstract}

Keywords: soxhlet, candlenut, acetone, ethanol, n-hexane

\section{Pendahuluan}

Tanaman kemiri merupakan tanaman tropis yang dapat tumbuh subur pada tanah yang berpasir dan tanah yang kurang subur sekalipun. Tanaman ini biasanya ditemukan pada ketinggian 150 - 1000 meter di atas permukaan laut [6].

Di daerah Sumatera, khususnya di Taman Nasional Leuser, kemiri merupakan salah satu produk yang hasil produksinya terbesar di antara produk hutan yang lain (NTFP: Non Timber Forest Product) [3].

Dari tahun 2004 ke tahun 2005, data ekspor minyak kemiri mengalami peningkatan hingga dua kali lipat. Selain itu harga ekspor minyak kemiri juga mengalami peningkatan. Hal ini menunjukkan minyak kemiri semakin dibutuhkan di negara lain [2].

\section{Teori}

Biji kemiri mengandung 50\% - 60\% berat minyak. Minyak kemiri dapat diperoleh dengan cara diperas ataupun dengan cara ekstraksi. Jika diperas dalam kondisi dingin, minyak yang keluar akan berwarna kuning muda serta rasa dan bau yang enak. Namun jika diperas dalam kondisi yang panas, minyak yang keluar akan berwarna gelap serta bau dan rasanya tidak enak [1], [5].

Minyak kemiri mempunyai sifat-sifat unik, yaitu minyak ini mudah mengering bila dibiarkan di udara terbuka. Oleh karena itu minyak kemiri 
dapat digunakan sebagai minyak pengering dalam industri minyak dan varnish. Minyak pengering memiliki derajat ketidakjenuhan yang tinggi karena sebagian besar tersusun oleh asam lemak tak jenuh dan memiliki sifat mudah teroksidasi dan membentuk polimer berupa lapisan film [7]. Minyak kemiri memiliki bilangan iodin 136 - 167 berarti memiliki kandungan asam lemak tak jenuh yang tinggi dan memang dapat berfungsi sebagai minyak pengering.

Selain itu, minyak biji kemiri juga dapat terbakar sehingga dapat digunakan sebagai bahan bakar, misalnya bahan bakar untuk penerangan dan bahkan sekarang ini sudah mulai diteliti kegunaan minyak kemiri untuk dijadikan bahan bakar kendaraan bermotor pengganti solar, yaitu biodiesel. Minyak kemiri yang dihasilkan per hektar tanaman kemiri adalah 1800 - 2700 liter dengan ekivalen energi 17000 - $25500 \mathrm{kWh}$ [8].

\section{Metodologi Penelitian}

Metode penelitian yang akan dilakukan meliputi penentuan kandungan air biji, pengecilan ukuran biji kemiri, dan ekstraksi Soxhlet biji kemiri. Pelarut yang akan digunakan adalah aseton, etanol, dan n-heksana. Pemisahan minyak kemiri dari pelarut pengekstrak dilakukan dengan evaporasi vakum. Analisis terhadap minyak kemiri yang diperoleh meliputi analisis rendemen, bilangan asam, bilangan iodin, bilangan penyabunan, kadar air, indeks bias, massa jenis.

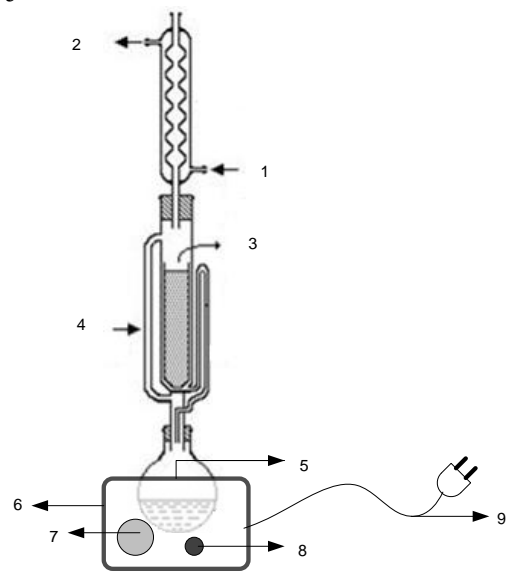

Keterangan: (1) Air pendingin masuk kondensor; (2) Air pendingin keluar kondensor; (3) Tudung berisi sampel sumber minyak; (4) Saluran uap naik; (5) Pipa kapiler; (6) Heating mantle; (7) Pengatur panas; (8) Lampu indikator; (9) Kabel listrik

\section{Gambar 1. Peralatan Ekstraksi Soxhlet}

Bahan baku yang digunakan adalah biji kemiri dan larutan pengekstrak (aseton, etanol, dan n-heksana). Peralatan ekstraksi Soxhlet yang digunakan dapat dilihat pada Gambar 1.

\section{Hasil}

\section{Fenomena Ekstraksi Soxhlet}

Pada skala pemanasan yang sama, waktu refluks yang paling singkat terjadi pada pelarut n-heksana. Senyawa ini memiliki titik didih yang paling rendah dibandingkan etanol dan aseton. Aseton dalam keadaan murni memang memiliki titik didih yang lebih rendah. Tabel 1 menunjukkan sifat fisik dari pelarut yang digunakan.

Tabel 1. Sifat Fisik Pelarut

\begin{tabular}{|c|c|c|c|}
\hline Pelarut & $\begin{array}{c}\text { Titik } \\
\text { Didih } \\
\left({ }^{\mathbf{0}} \mathbf{C}\right)\end{array}$ & $\begin{array}{c}\text { Konstanta } \\
\text { dielektrik }\end{array}$ & $\begin{array}{c}\text { Densitas } \\
(\mathbf{g r} / \mathbf{m l})\end{array}$ \\
\hline n-heksana & 69 & 2.0 & 0.655 \\
\hline Benzena & 80 & 2.3 & 0.879 \\
\hline Etanol & 79 & 24 & 0.789 \\
\hline Aseton & 56 & 21 & 0.786 \\
\hline Metanol & 65 & 33 & 0.791 \\
\hline
\end{tabular}

Namun aseton yang digunakan dalam percobaan adalah aseton teknis. Hal ini menunjukkan bahwa kadar air aseton yang digunakan cukup tinggi. Tabel 2 menunjukkan titik didih pelarut saat penelitian

Tabel 2. Titik didih saat penelitian

\begin{tabular}{|c|c|}
\hline Pelarut & Temperatur rata-rata \\
\hline Etanol & $80^{\circ} \mathrm{C}$ \\
\hline Aseton & $75^{\circ} \mathrm{C}$ \\
\hline n-Heksana & $70^{\circ} \mathrm{C}$ \\
\hline
\end{tabular}

Selama proses ekstraksi berlangsung, temperatur yang terbaca pada termometer akan sedikit meningkat karena semakin lama jumlah minyak dalam labu meningkat. Hal ini dicegah dengan penggunaan pelarut dalam perbandingan yang besar terhadap massa biji yang akan diekstraksi. Warna kuning larutan di labu bundar paling tua ketika digunakan pelarut etanol, disusul oleh aseton, dan yang paling muda adalah n-heksana. Etanol merupakan senyawa 
pengekstrak zat warna yang baik. Oleh karena itu, pelarut ini menghasilkan warna larutan yang lebih tua.

\section{Analisis Rendemen}

Kurva rendemen pada ekstraksi Soxhlet dapat dilihat pada Gambar 2. Rendemen tertinggi diperoleh saat digunakan pelarut n-heksana sedangkan yang terendah adalah pelarut etanol. Urutan konstanta dielektrik mulai dari yang paling jauh sampai yang paling dekat dengan konstanta dielektrik minyak adalah etanol, aseton, n-heksana. Rendemen hasil ekstraksi Soxhlet memberikan kecenderungan yang sama. Urutan rendemen dari yang paling rendah sampai yang paling tinggi adalah etanol, aseton, n-heksana. Hal ini membuktikan minyak dapat dengan mudah terekstrak oleh pelarut yang memiliki konstanta dielektrik yang dekat atau dapat dikatakan sama-sama non-polar.

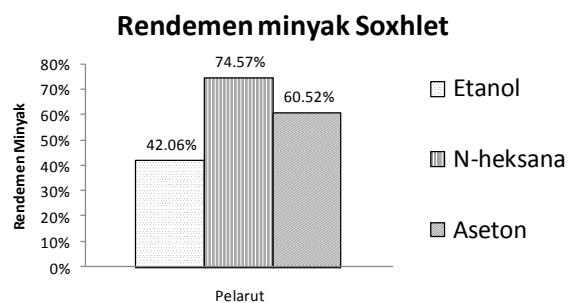

Gambar 2. Rendemen Minyak Hasil Ekstraksi

\section{Bilangan Asam}

Bilangan asam minyak proses Soxhlet dari yang paling tinggi adalah n-heksana, aseton, dan etanol. Kecenderungan ini disebabkan oleh temparatur ekstraksi minyak pada proses Soxhlet. Titik didih rata-rata yang terbaca pada termometer, pada saat percobaan, dari yang paling rendah adalah n-heksana, aseton, dan etanol. Kecenderungan ini sama dengan peningkatan bilangan asam yang terjadi.

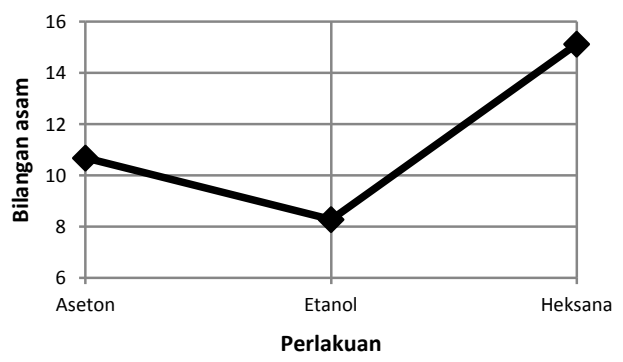

Gambar 3. Bilangan Asam Minyak Kemiri
Enzim merupakan senyawa protein yang pada suhu tinggi dapat menjadi tidak aktif, rusak, atau terdenaturasi. Kemungkinan kecenderungan yang sama ini diakibatkan oleh titik didih masing masing pelarut yang juga mempengaruhi temperatur pemanasan pada saat ekstraksi. Bilangan asam minyak hasil ekstraksi dapat dilihat pada Gambar 3.

\section{Bilangan Penyabunan}

Rentang bilangan penyabunan minyak hasil ekstraksi adalah 145 - 175. Pelarut cenderung mengekstrak senyawa yang memiliki berat molekul rendah dan terbawanya pelarut pada minyak. Hal ini mungkin disebabkan kemiripan kepolaran pelarut dan kepolaran senyawa yang terekstrak. Tidak ada kecenderungan bilangan penyabunan terhadap temperatur maupun jenis pelarut. Bilangan penyabunan minyak dapat dilihat pada Gambar 4.

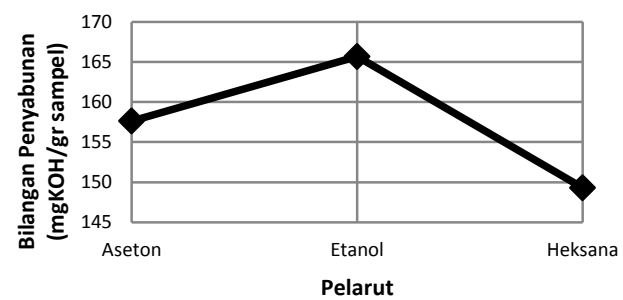

Gambar 4. Bilangan Iodin Minyak Kemiri

\section{Bilangan Iodin}

Naik turunnya bilangan iodin disebabkan oleh perbedaan jenis trigliserida atau senyawa yang terdapat dalam biji kemiri yang terekstrak pada masing-masing variasi.

Dugaan jenis asam lemak yang terdapat dalam jumlah yang dominan dalam minyak kemiri adalah asam oleat, asam linoleat, asam linolenat, asam palmitat, dan asam stearat. Asam lemak yang jenuh adalah asam palmitat dan stearat, sedangkan sisanya tidak jenuh dengan jumlah ikatan rangkap yang berbeda-beda.

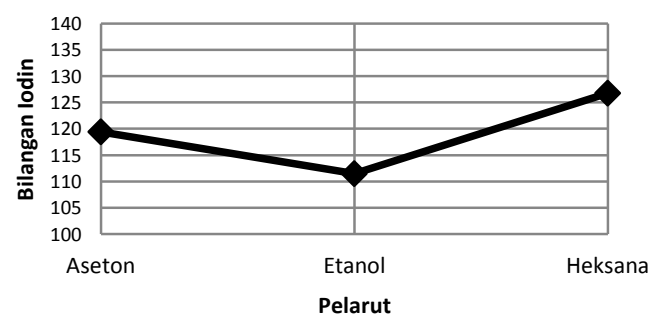

Gambar 5. Bilangan Penyabunan Minyak Kemiri 
Rendahnya bilangan iodin menunjukkan asam lemak jenuh terekstrak dalam jumlah yang cukup besar. Bilangan iodin minyak hasil ekstraksi dapat dilihat pada Gambar 5.

\section{Kadar Air}

Pelarut yang digunakan memiliki spesifikasi teknis, sehingga masih ada air yang terkandung di dalamnya. Air ini larut dalam minyak dan terbawa pada minyak, namun dapat dikatakan dalam kadar yang sangat rendah.

Etanol dan aseton termasuk senyawa yang cenderung polar sehingga mudah larut dalam air atau air mudah larut dalam aseton dan etanol. Oleh karena itu, nilai kadar air dari minyak hasil ekstraksi Soxhlet aseton dan etanol lebih tinggi dibandingkan pelarut n-heksana. Kadar air minyak hasil ekstraksi dapat dilihat pada Gambar 6.

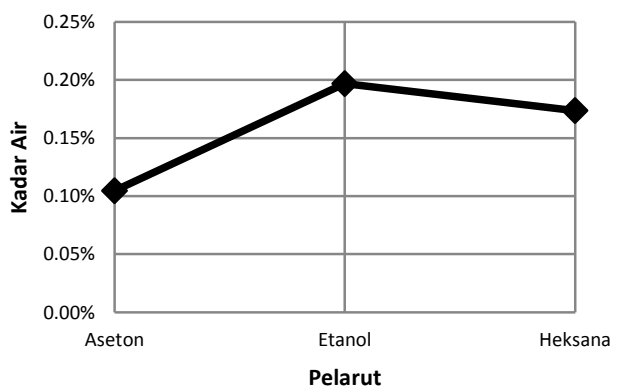

Gambar 6. Kadar Air Minyak

\section{Indeks Bias}

Indeks bias minyak hasil ekstraksi cenderung sama untuk ketiga pelarut. Hal ini menunjukkan jenis pelarut tidak mempengaruhi indeks bias minyak kemiri. Indeks bias minyak dapat dilihat pada Gambar 7.

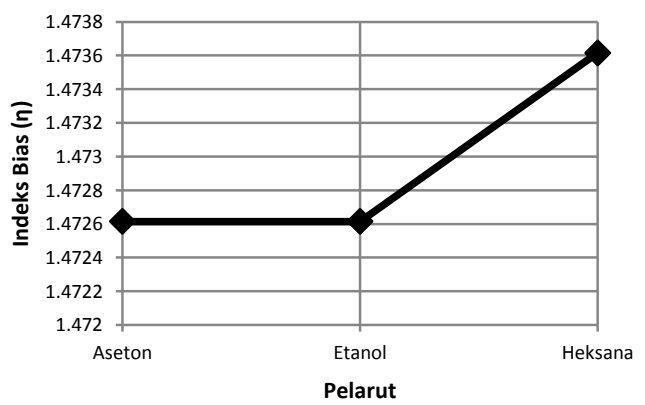

Gambar 7. Indeks Bias Minyak

\section{Massa Jenis}

Densitas minyak dipengaruhi oleh $\mathrm{M}_{\mathrm{r}}$ dan derajat ketidakjenuhan. Makin tinggi derajat ketidakjenuhan dan makin rendah $\mathrm{Mr}$, semakin rendah massa jenis minyak ${ }^{[4]}$. Dengan kata lain, ada hubungan antara massa jenis minyak dengan bilangan penyabunan dan bilangan iodin. Selain $i t u$, oksidasi cenderung memperbesar $\rho$, sedang kehadiran asam lemak bebas cenderung menurunkannya.

Pelarut pada proses Soxhlet yang menghasilkan massa jenis dari yang paling tinggi sampai yang paling rendah adalah n-heksana, aseton, dan etanol. Kecenderungan ini tidak sesuai dengan kecenderungan bilangan asam dan bilangan iodinnya, namun sesuai dengan kecenderungan bilangan penyabunannya. Semakin tinggi berat molekul, semakin rendah massa jenis yang dihasilkan. Analisis bilangan penyabunan pada proses Soxhlet dari yang paling rendah sampai yang paling tinggi adalah nheksana, aseton, dan etanol. Densitas minyak dapat dilihat pada Gambar 8.

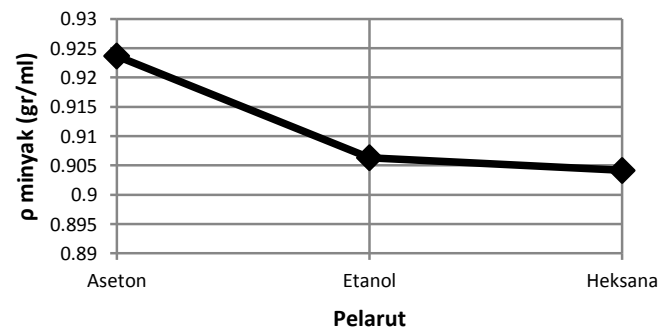

\section{Gambar 8. Densitas Minyak Kemiri}

\section{Kesimpulan}

Kesimpulan yang dapat diberikan pada penelitian ini adalah:

1. Pelarut yang paling cocok digunakan dalam ekstraksi minyak dari biji kemiri untuk mendapatkan rendemen maksimal adalah nheksana.

2. Pelarut yang paling cocok untuk ekstraksi minyak dari biji kemiri untuk mendapatkan kualitas terbaik adalah etanol dengan nilai bilangan asam 8,27 gram KOH/gram minyak.

3. Kandungan minyak dalam biji kemiri adalah $74,57 \%$ yang diperoleh dari metode ekstraksi Soxhlet dengan pelarut n-heksana.

\section{Daftar Pustaka}

[1] Armstrong, W.P., , Candlenuts and Kukui Nuts, http://waynesword.palomar.edu, diakses pada 19 Februari 2008. 
[2] Badan Pusat Statistik Jawa Barat, Data Produksi Kemiri Jawa Barat, www. jabar.bps.go.id, 1998, diakses pada 4 Maret 2008.

[3] Badan Pusat Statistik Pada Ekosistem Leuser, Data Produksi Hasil Hutan di Taman Nasional Leuser, www.aceh.bps.go.id, 1999, diakses pada 5 April 2008.

[4] Eckey, E. W., Vegetable Fats and Oils, Reinhold, New York, 1954.

[5] Hakim, Amini Lukman, Kemungkinan Pemanfaatan Minyak Kemiri dalam Farmasi \& Makanan, Universitas Gajah Mada, Yogyakarta, 1984.

[6] Ketaren, S., Pengantar Teknologi Minyak dan Lemak Pangan, Universitas Indonesia, Jakarta, 1986.

[7] Maharani, Geovanni skripsi sarjana, Pengaruh Ukuran Partikel Biji Kemiri (Aleurites Moluccana (L.) Willd) Dan Jenis Pelarut dalam Ekstraksi Batch Terhadap Pembuatan Minyak Kemiri, Universitas Katolik Parahyangan, Bandung, 2002.

[8] Purwanto, Peningkatan Produktivitas Singkong Dengan Teknologi Mukibat Sebagai Sumber Bahan Baku Bioetanol, Universitas Gajah Mada, Yogyakarta, 2007. 